\title{
First report of "jewel wasp" Ampulex compressa (Fabricius, 1781) (Hymenoptera: Ampulicidae) in the Amazon Biome of Brazil
}

\author{
Pires, EM. ${ }^{a *}$, Campos, AK. ${ }^{a}$, Pereira, MR. ${ }^{a}$, Nogueira, RM. ${ }^{a}$, Campos, LAO. ${ }^{b}$, \\ Moreira, PSA. ${ }^{a}$ and Soares, MA. ${ }^{c}$
}

anniversidade Federal de Mato Grosso - UFMT, Av. Alexandre Ferronato, 1200, Setor Industrial, CEP 78550-000, Sinop, MT, Brazil

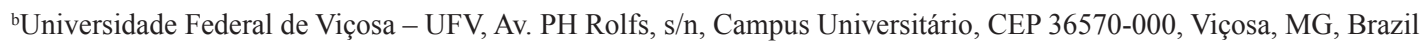
'Universidade Federal dos Vales do Jequitinhonha e Mucuri - UFVJM, Rod. MGT 367, km 583, 5000, Alto da Jacuba, CEP 39100-000, Diamantina, MG, Brazil

*e-mail: evaldo.pires@gmail.com

\section{Received: April 28, 2013 - Accepted: July 22, 2013 - Distributed: November 30, 2014}

(With 1 figure)

Ampulex compressa (Fabricius, 1781) is a wasp of the family Ampulicidae, subfamily Ampulicinae and tribe Ampulicini, with 217, 22 and 16 species reported, respectively (Amarante, 2002; Buys, 2007). This insect presents a metallic body colour pattern, usually in blue or green, and this colouring is responsible for $A$. compress $a$ being popularly known as "jewel wasp" or "emerald wasp."

Regarding reproductive/evolutionary aspects, A. compressa presents a direct relationship with some specimens of cockroaches (Blattaria: Blattidae) like
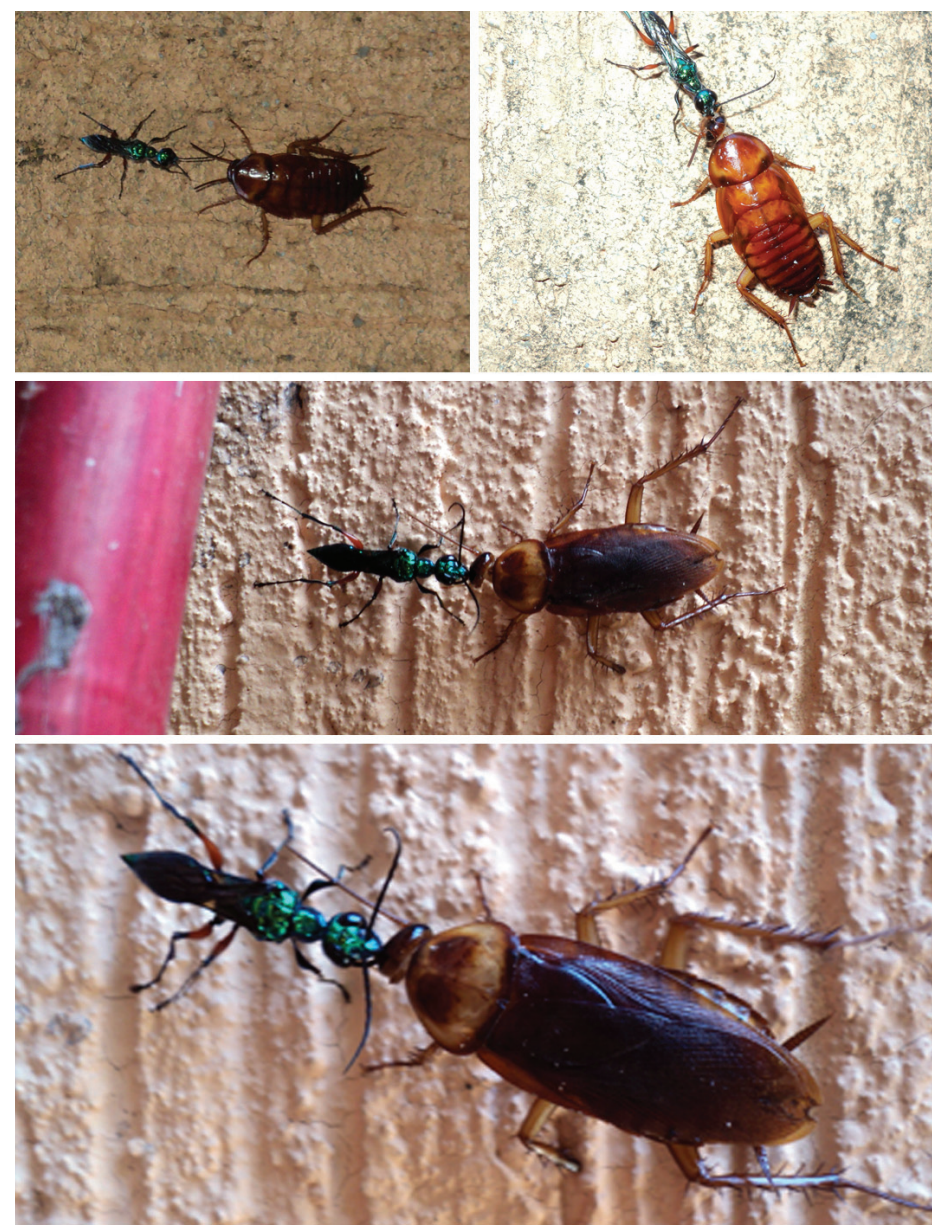

Figure 1. Female of Ampulex compressa (Hymenoptera: Ampulicidae) attacking immatures and adults of Periplaneta americana (Blattodea: Blattidae) 
Periplaneta americana (Linnaeus, 1758), Periplaneta australasiae (Fabricius, 1775) and Neostylopiga rhombifolia (Stoll, 1813) (Bohart and Menke, 1976), whereby besides preying on adults and immatures, it uses the body of the prey as a receptacle for laying and development of eggs and larvae (Fox et al., 2009).

Some authors report the potential of $A$. compressa as a biological control agent of $P$. americana (Veltman and Wilhelm, 1991; Lebeck, 1991). On the other hand, other authors explain that this species has no potential as a natural enemy to be used effectively in biological control programmes, because they do not hunt regularly (Williams, 1942).

The geographic distribution has been reported originally in Ethiopian and Oriental Regions (Bohart and Menke, 1976). In the Americas, this species has been found in Brazil, USA (Hawaii) and Venezuela (Amarante, 2002; Menke and Yustiz, 1983), where the only reports of its occurrence were in the states of Rio de Janeiro and São Paulo (Amarante, 2002), which are located in the Atlantic Forest Biome.

The wasp specimens were identified by Prof. Dr. Evaldo Martins Pires from the Federal University of Mato Grosso as Ampulex compressa. These insects were found in urban areas in the municipality of Sinop, Mato Grosso state $\left(11^{\circ}\right.$ 50' 19.3" S; 55 29' 43.2" W and elevation of $369 \mathrm{~m}$ ), near an area of environmental conservation (Sinop Forest Park) which has an area of approximately 105 hectares. This park may be characterised a fragment of the Amazon rainforest where the native forest remains partially preserved and presents a large biodiversity in relation to regional flora and fauna. These insects were observed throughout the entire year of 2012, attacking adult and immature forms of $P$. americana (Figure 1). The specimens collected were prepared, identified, labelled and added to the biological collection located in the "Acervo Biológico da Amazônia
Meridional" of the Universidade Federal de Mato Grosso, in Sinop, Mato Grosso.

This study aimed to contribute to the records on the geographical distribution of the jewel wasp, which needs more studies regarding the distribution, phylogeny, ecology and control of $P$. americana.

\section{Acknowledgements}

To those who have never lacked inspiration to present what nature has allowed us to elucidate.

\section{References}

AMARANTE, STP., 2002. A synonymic catalog of the Neotropical Crabronidae and Sphecidae (Hymenoptera: Apoidea). Arquivos de Zoologia, São Paulo, vol. 37, no. 1, p. 1-139. http://dx.doi. org/10.11606/issn.2176-7793.v37i1p1-139.

BOHART, RM. and MENKE, AS., 1976. Sphecid wasps of the world a generic revision. London: University of California Press, $695 \mathrm{p}$.

BUYS, SC., 2007. Morphological studies on the last instar larva of Ampulex compressa (Fabricius) from Brazil (Insecta, Hymenoptera, Ampulicidae). Spixiana, vol. 30, no. 1, p. 33-37.

FOX, EGP., NASCIMENTO, SB. and EIZEMBERG, R., 2009. Notes on the biology and behavior of the jewel wasp, Ampulex compressa (Fabricius, 1781) (Hymenoptera; Ampulicidae), in the laboratory, including first record of gregarious reproduction. Entomological News, vol. 120, no. 4, p. 430-437.

MENKE, AS. and YUSTIZ, E., 1983. Ampulex compressa (F) in Venezuela (Hymenoptera, Sphecidae). Proceedings of the Entomological Society of Washington, vol. 85, no. 1, p. 180-180.

WILLIAMS, FX., 1942. Ampulex compressa (Fabr.), a cockroachhunting wasp introduced from New Caledonia into Hawaii. Proceedings of the Hawaiian Entomological Society, vol. 11, no. 2, p. 221-233. 